\title{
INDUCED POLYPLOIDIZATION IN BRASSICA CAMPESTRIS L. (BRASSICACEAE)
}

\begin{abstract}
Present experimental design has been made up to obtain crop with higher ploidy level via synthetic polyploidization. Since ploidy manipulation is generally associated with the obtainment of some increased enviable traits of the crop and also provides them greater adaptability to unfavorable or harsh circumstances as compared to its diploids counterparts. Thus, herein present research autotetraploids of Brassica campestris L. have been lucratively achieved by the application of colchicine. Two methods of treatment were utilized i.e. seed treatment and seedling treatment. No polyploidy could be obtained through seed treatment while seedling treatment responded well towards polyploidy. However, the status of autotetraploidy has been confirmed by cytomorphological investigations of treated plants as against its diploids counterparts. For the purpose, morphological parameters such as increased stomata size, pollen diameter, flower size, reproductive organs whereas reduction in plant height, leaf length, leaf breadth, stomata frequency, number of flowers/inflorescence etc. were appraised. Further, cytological observations were made that had clearly revealed the doubling of genome in the autotetraploids as compared to diploids. Meanwhile, pollen fertility and size of pollen grains were evaluated as well.
\end{abstract}

Keywords: autotetraploid, Brassica campestris L., colchicine, diploid.

Introduction. Polyploidy, i.e., the possession of more than three complete sets of chromosomes has been a pivotal factor in plant evolution [1]. Hence, from ancient to contemporary polyploidization is considered as an ongoing and recurrent process that has also been acknowledged as an invaluable force for characterization of evolutionary trends in plants. Moreover the genome doubling (polyploidy) has been regarded as a pervasive force in plant evolution [2]. It might be responsible for adaptation and variation among similar or different kind of plant species. Recent estimates suggest that $70 \%$ of all angiosperms have experienced one or more episodes of polyploidization [3] and most flowering plant species have evolved through one or more round of polyploidy either by doubling of chromosome number with in a species (autopolyploidy) or by

(C) G. KUMAR, K. DWIVEDI, 2014 combining chromosome sets from distinct but related species (allopolyploidy). Topical studies convincingly demonstrate that polyploidy entails far more than mere merger of two genomes who passively acquiescence to their sudden collaboration but instead involve a whole spectrum of molecular and physiological adjustments [2].

Moreover, induced polyploidy offers some benefits for horticulture, pharmaceutical and agricultural improvement of plants [4]. For instance, higher ploidy level was associated with increased flower size in rhododendron and intensified flower colors in carnation and cyclamen $[5,6]$ and this manipulation in ploidy is also significant for genetic improvement of many plants [7] often generates variants that may possess useful characteristics and by doubling the gene products it also provides a wider germplasm base for breeding studies. Many researchers have induced polyploidy in several plant species through the antimitotic chemical, colchicine $\left(\mathrm{C}_{22} \mathrm{H}_{25} \mathrm{NO}_{6}\right)$ [8-10] which is obtained from the seeds and bulbs of the plant Colchicum autumnale L. More importantly without damaging any other life processes of the chromosomes, colchicine effects a temporary inactivation of the spindle mechanism, both the exterior part working from the centrosomes and the interior centromeric part [11]. Among various antimicrotubular drugs colchicine has proven to be the most useful to double the chromosome numbers of numerous crop species, including decorative flowers, medical and agricultural plants [12].

Before going ahead we wish to mention that, rapeseed is a group of oilseed crops which assumes the significance by occupying third rank among the oilseed crops after soybean and oil palm in production of vegetable oils in the international oilseed market [13]. It is among the oldest cultivated plant in human civilization. The oilseed crop belongs to the family Brassicaceae, cultivated throughout the world with several species and types as oilseed crops, vegetables and forage crops [14]. They are also used in the production of condiments and recognized as 


\section{G. Kumar, K. Dwivedi}

a valuable source of dietary fiber and moreover, Brassica vegetables contain little fat, and are sources of vitamins, minerals, and fiber [14]. However, its cake obtained after crushing of seeds is highly nutritious for cattle due to containing some amount of protein hence extensively used as cattle feed.

Thus, in view of considerable economic importance of Brassica campestris L., the present work has been aimed to obtain polyploid mutant lines by the implementation of colchicine in Brassica campestris $\mathrm{L}$. which were verified on basis of significant differences in various phenotypic traits of autotetraploid over its diploid counterparts. Thereby, resulting genome doubling or ploidy manipulation could be correlated with the enhancement of various economically important traits.

Materials and methods. Inbred seeds of cultivar Brassica campestris L. (Accession numberIC363713) were obtained from National Bureau of Plant Genetic Resources (NBPGR), New Delhi.

Colchicine used in present work was manufactured by Loba Chemie Pvt. Ltd. Mumbai (India). Two methods were utilized for polyploidization 1 -seed treatment and 2-seedling treatment. No polyploidy could be obtained via seed treatment however seedlings treatment responded well and showed positive response towards polyploidy. To assess polyploidy, healthy, dry and homogeneous seeds of Brassica campestris were washed and presoaked in distilled water for 2 hours, excess water was removed by drying seeds on blotting paper, sown in pots in triplicates at each dose. Concurrently, control was maintained. After 7 days' of germination when seedlings reached $2-3 \mathrm{~cm}$ in length, they were treated with different concentrations of aqueous solution of colchicine $\left(\mathrm{C}_{22} \mathrm{H}_{25} \mathrm{NO}_{6}\right)$ viz., $0.3,0.4,0.5,0.6 \%$. For this sterilized cotton balls were dipped in $0.3 \%$ concentration of colchicine then placed on the growth apex of young seedlings for 12, 24 and 36 consecutive hours along with the recovery of 12 hours and the similar methods were repeated for each dose. The pots were covered with perforated thin plastic sheets as a measure to check evaporation. Cotton balls were removed and apical tips were washed with tap water for proper growth and recovery.

Deformed preliminary leaves and delayed growth rate have been noticed just after colchinization. Furthermore, length and breadth of stomata has been documented and their frequency of occurrence were measured since stomata based analyses has been proved very significant to confirm induction of polyploidy before the cytological observations. For the purpose, young leaves were peeled off from its dorsal surface, stained with safranin for few minutes and washed thoroughly and mounted in glyce-

Table. 1. Colchicine treatment in seedlings of Brassica campestris $\mathbf{L}$.

\begin{tabular}{|c|c|c|c|c|c|c|c|}
\hline \multirow{2}{*}{ Concentration, $\%$} & \multirow{2}{*}{$\begin{array}{c}\text { Duration } \\
\text { (hours) }\end{array}$} & \multirow{2}{*}{$\begin{array}{c}\text { Number of } \\
\text { seedlings } \\
\text { treated }\end{array}$} & \multirow{2}{*}{$\begin{array}{c}\text { Plants } \\
\text { survived }\end{array}$} & \multirow{2}{*}{$\begin{array}{l}\text { Expected } \\
\text { polyploids }\end{array}$} & \multirow{2}{*}{$\begin{array}{l}\text { Reverted } \\
\text { plants }\end{array}$} & \multicolumn{2}{|c|}{$\begin{array}{c}\text { Confirmed auto- } \\
\text { tetraploids * }\end{array}$} \\
\hline & & & & & & No. & $\%$ \\
\hline \multicolumn{8}{|c|}{ Overnight treatment $6.00 \mathrm{pm}-6.00 \mathrm{am}$} \\
\hline 0.3 & 12 & 30 & 29 & 9 & 9 & - & - \\
\hline 0.3 & 24 & 30 & 25 & 15 & 15 & - & - \\
\hline 0.3 & 36 & 30 & 29 & 27 & 25 & 2 & 6.66 \\
\hline 0.4 & 12 & 30 & 27 & 12 & 12 & - & - \\
\hline 0.4 & 24 & 30 & 24 & 9 & 9 & - & - \\
\hline 0.4 & 36 & 30 & 27 & 15 & 15 & - & - \\
\hline 0.5 & 12 & 30 & 27 & 12 & 12 & - & - \\
\hline 0.5 & 24 & 30 & 21 & 21 & 21 & - & - \\
\hline 0.5 & 36 & 30 & 21 & 18 & 17 & 1 & 3.33 \\
\hline 0.6 & 12 & 30 & 27 & 18 & 15 & 3 & 10 \\
\hline 0.6 & 24 & 30 & 21 & 24 & 24 & - & - \\
\hline 0.6 & 36 & 30 & 27 & 24 & 23 & 1 & 3.33 \\
\hline
\end{tabular}

* Confirmed by meiotic observation. 

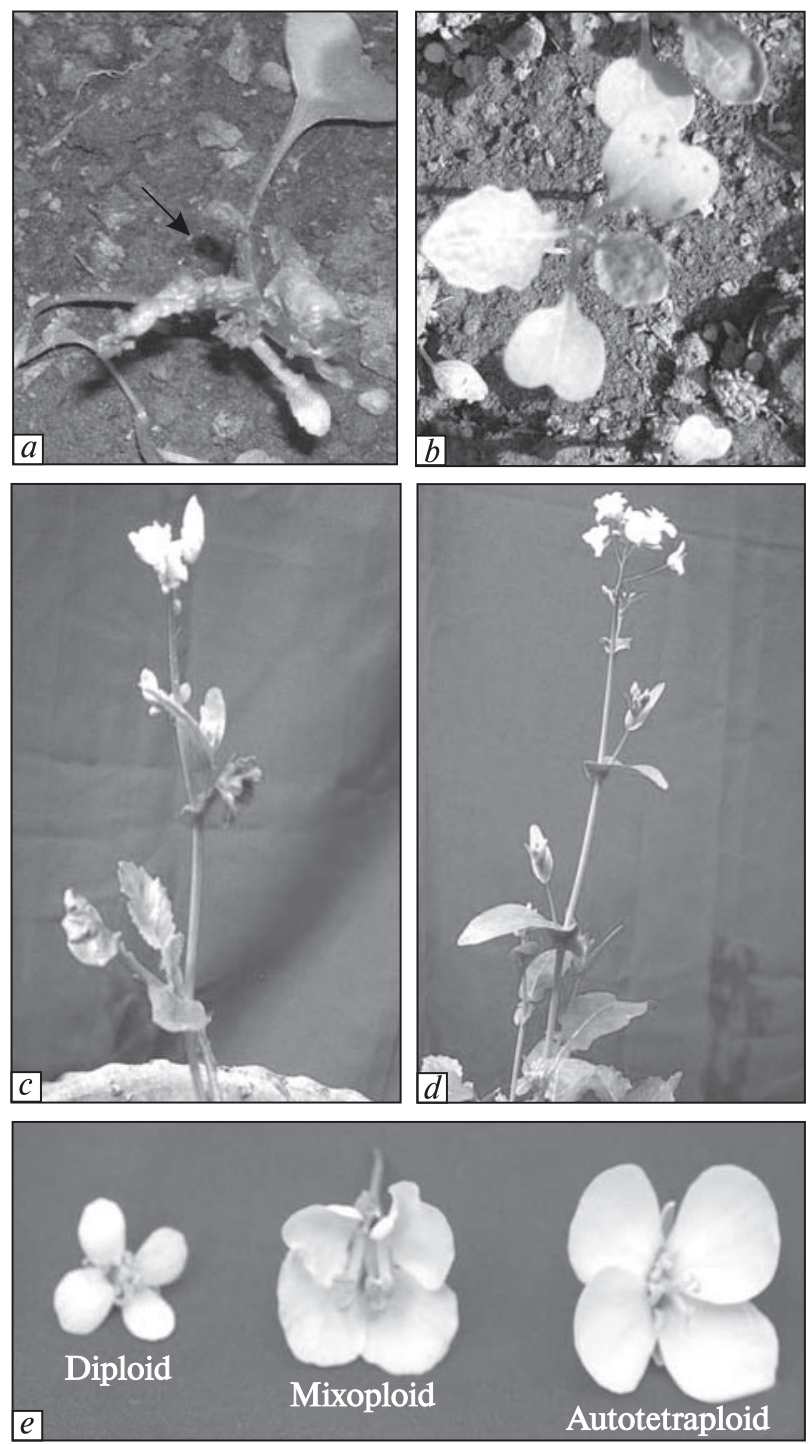

rin gel, observed under optical microscope. Length and breadth of stomata was measured using ocular micrometer in different views and their mean values were calculated. Morphological characters such as plant height, leaf length and breadth etc. have been documented. Large sized young flower buds and remarkable increase in flower size with less number of flowers per inflorescence were also marked.

For meiotic preparation, small sized floral buds were fixed in glacial acetic acid : ethyl alcohol $(1: 3, \mathrm{v} / \mathrm{v})$ and then transferred to $70 \%$ alcohol and refrigerated at $4{ }^{\circ} \mathrm{C}$ until use. After 24 hours slides were prepared by using anther squash technique with $2 \%$ standard aceto-carmine stain with

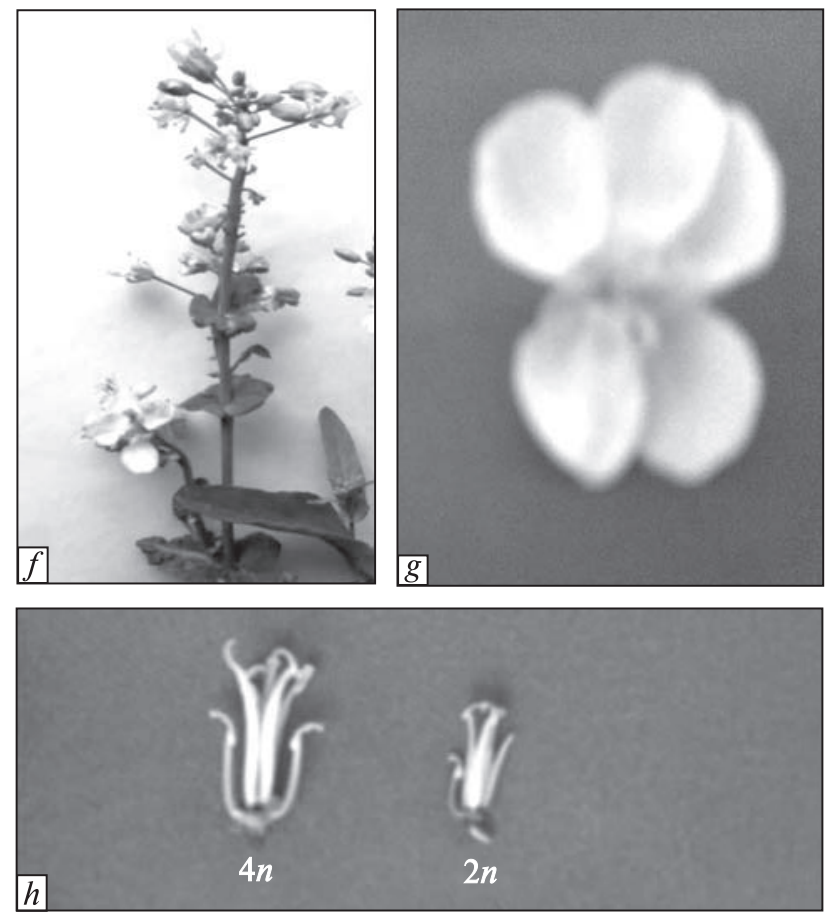

Fig.1. $a-$ deformed growth of seedling due to colchicine treatment; $b$ - normal seedling with newly formed vegetative (true) leaves; $c-$ an autotetraploid plant; $d-$ a diploid plant; $e-$ flowers of diploid $(2 n)$, mixoploid and autotetraploid $(4 n) ; f-$ a mixoploid plant; $g-$ a flower having five petals; $h$ - reproductive organs of autotetraploid $(4 n)$ and diploid $(2 n)$ where $4 n$ displays bigger reproductive organs

traces of ferric chloride [15] and observed under microscope (Olympus $\mathrm{CH} 2 \mathrm{Oi}$ ). Pollen viability was also recorded on the basis of pollen stainability test i.e. stained and filled pollen grains were considered as fertile however empty, small and shriveled were assumed as sterile. Photomicrographs were made by using Pinnacle PCTV captured device and statistical analyses have been done by using statistica- 8 software of stat-soft to measure mean values of variables.

Results. Genomic constitution of diploid plant was absolutely normal $(2 n=20)$ while, one fold increment in genomic constitution of Brassica campestris $\mathrm{L}$. was encountered in autotetraploid plants $(4 n=40)$. Out of 360 seedlings treated, only $23.32 \%$ 


\section{G. Kumar, K. Dwivedi}

of seedlings were confirmed as autotetraploids on morphological as well as cytological basis however, remaining percentage of treated seedlings either died or reverted (Table 1).

Morphological observations. Herein present case, preliminary manifestations of colchinization were delayed growth rate which was later found to be accelerated though unable to exceed that of diploid while diploid showed their regular way of growth pattern with normal plant height (Table 2). Later, treated juvenile seedlings showed elongated petioles of cotyledonary leaves and, emergence of highly deformed true leaves showing swelling, curling and rolling of lamina (Fig. 1, a) which were highly thicker, dark green, leathery and quite smaller as against diploids. However, some other phenotypic characters such as flower (cruciform) size (Fig. 1,e), stomata size (Fig. 1, $k$ ), pollen grains diameter (Fig. 1, $i$ ) and reproductive organs (Fig. $1, h$ ) have been increased vigorously in autotetraploid plants. Further $50 \%$ flowering were registered that showed delay of 11 days in autotetraploids as compared to diploids. Autotetraploids also exhibited less number of flowers per inflorescence; i.e., $14 \pm 0.86$, while it was $40 \pm 1.34$ in diploids, with marked large sized flowers in autotetraploid plants (Fig. 1,e). While more interestingly, few flowers having more than four petals (penta-petalous) with larger sized reproductive organ has been documented in present case (Fig. 1, $g, h$ ). Presence of five petals in Brassica is in fact a rare phenomenon observed in present case and never noticed earlier. Since Brassica crops strictly bear four petals which are reminiscent of a cross means «flowers with four petals in cross section» known as crucifers. Some other morphological features observed were plant height, leaf length, leaf breadth and number of inflorescences/plant which registered decline in its mean value over diploid.

Stomatal observation. Length of stomata in autotetrapoloids was $52.48 \pm 0.02 \mu \mathrm{m}$, although it was $27.97 \pm 0.21 \mu \mathrm{m}$ in diploids.

Similar difference in breadth has been observed in stomata (Fig. 1, $j, k$ ). In spite of bigger sized stomata, significant difference in the frequency of stomata (number of stomata $/ \mathrm{mm}^{2}$ ) of diploid and autotetarploid has been administered (Table 2).

Palynological observation. Pollen diameter in autotetraploid and diploid plants was $67.95 \pm 0.02$ and $26.05 \pm 0.28 \mu \mathrm{m}$, respectively. That clearly reveals the difference between pollen sizes in treated as well as non-treated plants. Thus, the majority of pollen grains in autotetraploids were bigger compared to diploids. A significant reduction in the pollen fertility of autotetraploids has been recorded (Table 2).

Thus, the above morphological observations clearly verify that the induced autotetraploid plants were robust, more compact bearing increased vegetative and reproductive organs, in short was superior over its diploid counterparts.

Cytological observation. The somatic complement of Brassica campestris L. is $2 n=20$ while doubling of chromosomes was found in induced autotetraploid. Fig. 2, $a-c$ clearly display the diaki-

Table 2. Comparative analyses of various morphological and physiological characters of diploids and induced autotetraploids (mean $\pm \mathrm{SE}$ )

\begin{tabular}{lcc}
\hline \multicolumn{1}{c}{ Characteristics } & Diploid $(2 n=20)$ & Autotetraploid $(4 n=40)$ \\
\hline Plant height, $\mathrm{m}$ & $1.46 \pm 0.04$ & $0.96 \pm 0.03^{*}$ \\
No. of flowers/inflorescence & $40.00 \pm 1.34$ & $14.00 \pm 0.86$ \\
Pollen diameter, $\mu \mathrm{m}$ & $26.05 \pm 0.28$ & $67.95 \pm 0.02$ \\
Stomata length, $\mu \mathrm{m}$ & $27.97 \pm 0.21$ & $52.48 \pm 0.02$ \\
Stomata breadth, $\mu \mathrm{m}$ & $15.08 \pm 0.24$ & $25.89 \pm 0.33$ \\
Frequency of stomata/mm ${ }^{2}$ & $21.20 \pm 0.50$ & $6.80 \pm 0.50$ \\
$50 \%$ flowering & $80.0 \pm 0.18$ & $91.00 \pm 0.47$ \\
Maturity & $142.00 \pm 0.45$ & $135.00 \pm 0.32$ \\
Pollen fertility, $\%$ & $98.66 \pm 0.26$ & $63.33 \pm 3.33$ \\
Leaf length, cm & $24.50 \pm 0.16$ & $16.91 \pm 1.32$ \\
Leaf breadth, cm & $8.44 \pm 0.71$ & $6.34 \pm 0.14$ \\
Number of inflorescence/plant & $11.40 \pm 0.86$ & $9.21 \pm 0.33$ \\
\hline
\end{tabular}



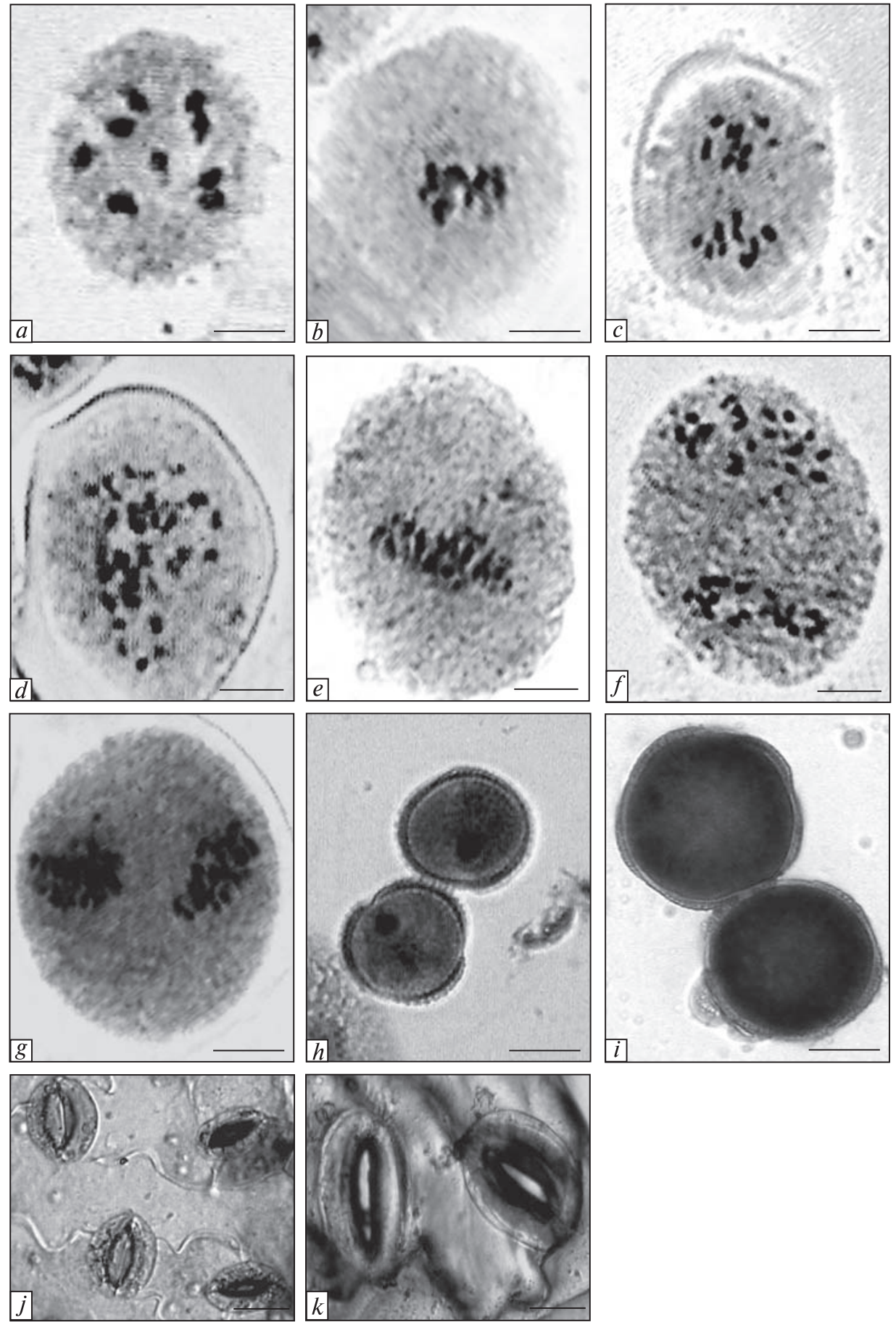

Fig. 2. $a$ - Normal PMC showing diakinesis $(n=10) ; b$ - Normal PMC showing metaphase-I $(2 n=20) ; c-$ Normal PMC showing anaphase-I (10:10); $d$ - PMC showing autotetraploid diakinesis; $e-$ PMC showing autotetraploid metaphase-I $(4 n=40) ; f$ - PMC showing autotetraploid anaphase-I; $g$ - PMC showing autotetraploid metaphase-II; $h$ - Typical tricolpate diploid pollen grains of diploid; $i$ - Bigger sized fertile tetracolpate and pentacolpate pollen grains of autotetraploid; $j$ - Stomata of diploids; $k$ - Stomata of colchicine induced autotetraploids (bigger sized stomata with decreased frequency of stomata/ $\mathrm{mm}^{2}$ over diploid). Scale bar: $a-i-4.2 \mu \mathrm{m} ; j-k-10 \mu \mathrm{m}$ 


\section{G. Kumar, K. Dwivedi}

nesis, metaphase-I and anaphase-I, respectively in diploids. Meiosis in PMCs of diploids was regular however, in treated plants, autotetraploid status could be confirmed by chromosomal doubling i.e., $4 n=40$ that showed the increment in the number of bivalents in PMCs of polyploids despite univalents and other association in some of the PMCs yet the frequency of their occurrence was almost negligible. Fig. 2, $d-g$ show diakinesis, metaphase-I, anaphase-I and metaphase-II, respectively in autotetraploid. Thus, on the basis of above observations, percentage of induced autotetraploid plants has been mentioned in Table 1. Notwithstanding polyploids, low frequency of mixoploids was also discernible in some case (Fig. 1, f).

Discussion. Polyploid plants may often possess superior agronomic traits over their diploid counterparts. For example, ployploids may have larger leaves and flowers, thicker stems and roots, darker green leaves, an increased width-to-length ratio of the leaves, increased cell size, leading to larger reproductive and vegetative organs a more compact growth habit and a higher tolerance to environmental stress [16-18]. On the basis of above mentioned facts, herein present study the utility of various morphological, physiological and cytological analyses in distinguishing autotetraploids from diploids has been tested.

Just after colchinization, number of plants was suspected for being polyploids though only few were confirmed as autotetraploid after cytological study and rest has been reverted and started to behaving as controls. The retarded growth rate might be due to the reduced rate of cell division that resulted from the physiological disturbance caused by colchicine [19]. Joshi et al. [20] recorded that polyploid plants were slower in growth initially, but later showed gigantism. They are generally larger than their diploid counterparts and frequently develop into thicker tissues, resulting in large sized plant organs [21]. Present investigation fully agreed with these findings i.e. thicker leaves, stem, increased reproductive organs etc. however some traits were found to be negatively correlated such as plant height, leaf length, leaf breadth etc. Though among them, decreased plant height of the autotetraploid has been found to be enviable since it prevent plant from being lodged. Lodging is a serious problem for oilseed crop and it reduces the yield capacity of crop. However increase in the number and size of the chloroplast with quantitative increase in the DNA content could be the considerable cause of the dark green thicker leaves of autotetraploids [22].

The relationship between flower sizes with number of flowers per inflorescence was found to be reciprocal. Differences in length of cruciform petals in polyploids and diploids were also prominent i.e. flowers in autotetraploids were noticeably larger over diploid which could be due to «gigas effect» which was an increase in polyploid cell size that often resulted in increased organ size throughout the plant [23]. Jana et al. [24] found that the autotetraploid individuals had larger flowers than their diploid counterparts more often than expected by chance and also documented that autopolyploid species and genera should have larger inflorescences than diploid species and genera. Bigger flowers in polyploids were also subsequently confirmed by various researchers [25-27]. The occurrence of five petals in some of the flowers of autotetraploids is ambiguous however it might be possible that colchicine induced disturbed male meiosis may lead to some disturbance in particular gene(s) that governs the typical «cross-bearing» four-petalous condition of the present crop thereby resulting more than 4-petals.

In plants stomatal analysis and pollen diameter provide an efficient mean for characterization of polyploidy as these characters generally increased in polyploids [28-31]. Cohen and Yao [32] produced tetraploid Zantedecsbia via in vitro colchicine treatment and primarily verify the status of tetraploid via stomatal analysis and found that stomatal analyses could be the most efficient criteria for ploidy confirmation. Similarly increase in the size of pollen diameter has been documented in present case which eventually concurred with the observation of the Jaskani et al. [33] who applied colchicine to watermelon and found the autotetraploid plants bearing bigger flowers with increased number of pollen colpi over diploids. Despite larger size of pollens, declining frequency of pollen viability has been discernible that in turn reduced the seed yield. Reduced pollen fertility and increased cell and organ size (gigas-effects) were considered as universal effects of artificial polyploidization [34-36].

We delve further in to the cytological observation that indeed, became difficult because of very

ISSN 0564-3783. Цитология и генетика. 2014. T. 48. № 2 
small and poorly differentiated chromosomes of Brassica and found that their identification through the ordinary cytogenetical techniques was extremely difficult [37]. Hence, it had been a difficult task to explore the exact number of bivalents especially in case of diploids. Yet, one fold increment of bivalent count was observed in case of autotetraploids compared to diploids due to colchicine treatment. The high frequency of bivalents in the autotetraploids might be due to small size of chromosomes or due to a gene favouring bivalents formation [38].

Treatments with $0.3 \%$ for 24 hours and $0.6 \%$ for 12 hours also possessed some mixo-ploids among the population of diploids and auto-tetraploids which could be justified by the fact that the antimitotic agent cannot reach all meristematic cells at the time of treatment [39]. Occurrence of mixoploids is a major problem in the recovery of autotetraploids [40].

Meiotic behavior of autotetraploids was almost normal except few instances of meiotic aberrations viz. univalents, laggards and spindle malfunctioning that might have compromised with the pollen fertility and resulted in the reduced fertility of crops. According to Biswas [41] presence of univalents in polyploids during reduction division indicated failure of chiasma formation or due to loss of chiasmata with the progress of meiosis.

Lastly, remove hyphen interests in polyploids have been renewed in the past decade following the discovery of multiple origins and pattern of polyploid formation [42].

Conclusion. The consequences of polyploidy have been of long-standing interests in genetics, evolution, and systemic [43]. Thus, from the above observations, we simply wish to infer that the application of colchicine to seedling is an efficient method for polyploidization especially in Brassica campestris L., Hence, it might be worthy to recommend that colchicine could be used to raise possible fertile autopolyploid mutant lines. However, these mutant lines also provide broader germplasm base for polyploid breeding and hence, could be utilized by breeders for production of economic important autotetraploid crops exhibiting superiority in quantitative and qualitative traits of crop compared to diploid parent.

We are grateful to N.B.P.G.R, New Delhi for providing inbred seeds of Brassica campestris L. accession number - IC363713. One of the authors (K. Dwivedi) is thankful to DST, New Delhi for providing financial assistance as Inspire Fellowship.

\section{G. Kumar, K. Dwivedi}

\section{ИНДУЦИРОВАННАЯ ПОЛИПЛОИДИЗАЦИЯ y BRASSICA CAMPESTRIS (BRASSICACEAE)}

Разработана экспериментальная схема получения сельскохозяйственных культур с более высокой плоидностью путем искусственной полиплоидизации. Изменение плоидности обычно связано с приобретением некоторых важных признаков у таких культур, а также обеспечивает их более высокую приспособляемость к неблагоприятным или суровым условиям внешней среды по сравнению с диплоидными аналогами. В настоящем исследовании представлено успешное получение автотетраплоидов Brassica campestris L. с помощью колхицина. Для этого применяли два метода обработки - семян и проростков. Никакой полиплоидии не обнаружено при обработке семян, тогда как после обработки проростков полиплоиды были получены. С помощью цитоморфологических исследований подтверждено наличие автотетраплоидности у обработанных растений по сравнению с их диплоидными аналогами. Для этого оценивали такие морфологические параметры, как увеличенные размер устьиц, диаметр пыльцы, размер цветка, репродуктивные органы, а также уменышенные высота растений, длина листа, ширина листа, частота устьиц, число цветков и соцветий. Более того, в результате цитологических исследований четко установлено удвоение генома у автотетраплоидов по сравнению с диплоидами. Наряду с этим в работе оценивали фертильность пыльцы и величину пыльцевых зерен.

\section{REFERENCES}

1. Kim J.S., Oginuma K., Tobe H. Syncyte formation in the microsporangium of Chrysanthemum (Asteraceae): a pathway to infraspecific polyploidy // J. Plant Res. 2009. - 122. - P. 439-444.

2. Adam K.L., Wendel J.F. Polyploidy and genome evolution in plants // Curr. Opin. Plant Biol. - 2005. 8. - P. 135-141.

3. Masterson J. Stomatal size in fossil plants: evidence for polyploidy in majority of angiosperms // Science. - 1994. - 264. - P. 421-423.

4. Ascough G.D., Erwin J.E., Staden J.V. Effectiveness of colchicine and oryzalin at inducing polyploidy in Watsonia lepida N.E. Brown // Hort Sci. - 2008. 43. - P. 2248-2251.

5. Yamaguchi M. Basic studies on the flower color breeding of carnation (Dianthus caryophillus L.) // Bull, F. Hort. Minmikyushu Univ. - 1989. - 19. - P. 1-78. 


\section{G. Kumar, K. Dwivedi}

6. Takamura T., Miyajima I. Colchicine induced tetraploids in yellow-flowered cyclamens and their characteristics // Sci. Hod. - 1996. - 65. - P. 305312.

7. Madon M., Clyde M.M., Hashim H. et al. Polyploidy induction of oil palm through colchicine and oryzalin treatments // J. Oil Palm Res. - 2005. - 17. P. 110-123.

8. Rey H.Y., Sansberro P.A., Collavino M.M. et al. Colchicine, trifluralin, and oryzalin promoted development of somatic embryos in Ilex paraguariensis (Aquifoliaceae) // Euphytica. - 2002. - 123. P. 49-56.

9. Pickens K.A., Cheng Z.M., Kania S.A. Effect of colchicine and oryzalin on callus and adventitious shoot formation of Euphorbia pulcherrirna Winter Rose // Hort Sci. - 2006. - 41, № 7. - P. 1651-1655.

10. Dhooghe E., Denis S., Eeckhaut I. et al. In vitro induction of tetraploids in ornamental Ranunculus // Euphytica. - 2009. - 168. - P. 33-40.

11. Levan $A$. The effect of colchicine on root mitosis in Allium // Hereditas. - 1939. - 24, № 4. - P. 471486.

12. Yemets A.I., Blume Ya.B. Progress in plant polyploidization based on antimicrotubular drugs // Open Hort. J. - 2008. - 1. - P. 15-20.

13. Kauser R., Athar H.R., Ashraf M. Chlorophyll florescence: a potential indicator for rapid assessment of water stress tolerance in Canola (Brassica napus L.) // Pak. J. Bot. - 2006. - 38, № 5. - P. 15011509 .

14. Cardoza V., Stewart Jr.C.N. Brassica biotechnology: progress in cellular and molecular biology // In Vitro Cell. Dev. Biol. Plant. - 2004. - 40. - P. 542-551.

15. Evans D.A., Reed S.M. Cytogenetic techniques // Plant Tissue Culture: Methods and Application in Agriculture / Ed. T.A. Thope. - New York : Acad. Press Inc, 1981. - P. 213-240.

16. Adaniya S., Shira D. In vitro induction of tetraploid ginger (Zingiber officinali Roscoe) and its pollen fertility and germinability // Sci. Hort. - 2001. - 88. P. 277-287.

17. Kermani M.J., Sarasan V., Roberts A.V. et al. Oryzalininduced chromosome doubling in Rosa and its effect on plant morphology and pollen viability // Theor. Appl. Genet. - 2003. - 107. - P. 1195-1200.

18. Shao J., Chen $C$., Deng $X$. In vitro induction of tetraploid in pomegranate (Punica granatum) // Plant. Cell. Tissue Org. Cult. - 2003. - 75. - P. 241-246.

19. Swanson C.P. Cytology and cytogenetics. - New Jersey, 1957. - $596 \mathrm{p}$.

20. Joshi P., Verma R.C. High frequency production of colchicine induced autotetraploids in faba bean ( $\mathrm{Vi}$ cia faba L.) // Cytologia. - 2004. - 69, № 2. P. 141-147.
21. Vainola A. Polyploidization and early screening of Rhododendron hybrids // Euphytica. - 2000. - 112. P. 239-244.

22. Butterfass T.H. A nucleotypic control of chloroplast reproduction // Protoplasma. -1983 . - 118. - P. 7174.

23. Stebbins G.L. Chromosomal evolution in higher plants. - London, 1971. - 216 p.

24. Vamosi J.C., Goring S.J., Kennedy B.F. et al. Pollination, floral display, and the ecological correlates of polyploidy // Func. Ecosyst. Commun. - 2007. 1, № 1. - P. 1-9.

25. Van Huylenbroeck J.M., de Riek J., de Loose M. Genetic relationships among Hibiscus syriacus, Hibiscus sinosyriacus and Hibiscus paramutabilis revealed by AFLP, morphology, and ploidy analysis // Genet. Res. Crop Evol. - 2000. - 47. - P. 335-343.

26. Husband B.C., Schemske D.W. Ecological mechanisms of reproductive isolation between diploid and tetraploid Chamerion angustifolium (Onagraceae) // J. Ecol. - 2000. - 88. - P. 689-701.

27. Medail F., Ziman S., Boscaiu O. et al. Comparative analysis of biological and ecological differentiation of Anemone palmata L. (Ranunculaceae) in the western Mediterranean (France and Spain) : an assessment of rarity and population persistence // Biol. J. Linn. Soc. - 2002. - 140. - P. 95-114.

28. Tan G.Y., Dunn G.M. Relationship of stomatal length and frequency and pollen grain diameter to ploidy level in Bromus inermis Leyss // Crop. Sci. - 1973. 13. - P. 332-334.

29. Przywara L., Pandey K.K., Sanders P.M. Length of stomata as an indicator of ploidy level in Actinidia deliciosa // New Zealand J. Bot. - 1988. - 26. P. 179-182.

30. De Jesus-Gonzalez L., Weathers P.J. Tetraploid Artemisia annua hairy roots produce more artemisinin than diploids // Plant Cell Rep. - 2003. - 21. P. 809-813.

31. Chauvin J.E., Souchet C., Dantec J.P., Ellissãche D. Chromosome doubling of $2 x$ Solanum species by oryzalin: method development and comparison with spontaneous chromosome doubling in vitro // Plant Cell Tissue Organ Cult. - 2003. - 73. - P. 65-73.

32. Cohen D., Yao J.L. In vitro chromosome doubling of nine Zantedeschia cultivars // Plant Cell Tissue Organ Cult. - 1996. - 47. - P. 43-49.

33. Jaskani M.J., Kwon S.W., Kim D.H. Flow cytometry of DNA contents of colchicine treated watermelon as a ploidy screening method at $\mathrm{m} 1$ stage // Pak. J. Bot. - 2005. - 37, № 3. - P. 685-696.

34. Stebbins G.L. Polyploidy in plants: unsolved problems and prospects // Polyploidy: Biological Relevance / Ed. W.H. Lewis. - New York : Plenum Press, 1980. P. 495-520. 
35. Lewis $W . H$. Polyploidy in species populations // Ibid. P. 103-144.

36. Talukdar D. Cytogenetic characterization of induced autotetraploids in grass pea (Lathyrus sativus L.) // Caryologia. - 2010. - 63, № 1. - P. 62-72.

37. Habib A., Shahida H., Khan A. Genome biology of the cultivated Brassica // Quarterly Sci. Vision, (Jul - Dec, 2003) and 3-4 (Jan - Jun, 2004), 9, P. 1-2.

38. Riley R., Chapman $V$. Genetic control of the cytologically diploid behaviour of hexaploid wheat // Nature. - 1958. - 182. - P. 713-715.

39. Marzougui N., Boubaya A., Thabti I. et al. Polyploidy induction of Tunisian Trigonella foenumgreaum $\mathrm{L}$. populations // Afr. J. Biotechnol. - 2011. - 10, № 43. - P. 8570-8577.
40. Kumar G., Yadav R.S. Impact of genome doubling on cytomorphological characters of Sesamum indicum L. (Pedaliaceae) // Chromosome Bot. - 2010. - 5, № 2. - P. 43-47.

41. Biswas S.C. Cytogenetic evaluation of induced variations through mutations and polyploidy in Lathyrus sativus L. and varietal diversities : Ph.D. thesis. Kalyani, India, 1998.

42. Soltis D.E., Soltis P.S., Tate J.A. Advances in the study of polyploidy since plant speciation// New Phytol. - 2003. - 161. - P. 173-191.

43. Wendel J.F. Genome evolution in polyploids // Plant Mol. Biol. - 2000. - 42. - P. 225-249.

Received 01.06.12 